\title{
Defensive Head-mimicry in Coralsnakes, Micrurus spp. (Squamata: Elapidae): Three New Records and a Review of Congeners Exhibiting this Behavior
}

\author{
Ronald Díaz-Flórez ${ }^{1}$, Carlos Brand ${ }^{2}$, and Alexandra Montoya-Cruz ${ }^{3}$
}

${ }^{1}$ Semillero de Investigación en Ecología y Conservación - SIEC, Universidad de La Salle, Bogotá, Colombia (ronalddias_10@hotmail.com [corresponding author]) ${ }^{2}$ Urabá Nature Tours, Antioquia, Colombia (urabanature@gmail.com)

${ }^{3}$ Grupo de Investigación de Evaluación, Manejo y Conservación de Recursos Hidrobiológicos y Pesqueros-GIREHPES, Universidad de los Llanos, Villavicencio, Colombia (alexandra.montoya@unillanos.edu.co)

$\mathrm{D}$ ifferent defensive strategies, acoustic, chemical, or visual (Rowe and Halpin 2013; Dalziell and Welbergen 2016), have been evolutionarily adopted by animals in response to predation (Brodie et al. 1991). Snakes exhibit a variety of anti-predatory strategies (Green 1988; Tozetti et al. 2009); however, knowledge of these mechanisms is scarce in some species (Lopes de Assis et al. 2020).

Over 80 species American coralsnakes in the genus Micrurus (Uetz et al. 2021), which are characterized by diverse patterns of aposematic coloration, exhibit a great diversity of antipredatory mechanisms that include body flattening, tailcoiling, head-hiding, hemipenal eversion, and cloacal discharge (DuVal et al. 2006; Serafim and Ribeiro Duarte 2008;
Getelina et al. 2020; Moore et al. 2020; Tozetti et al. 2021). Another defense strategy is head-mimicry, which consists of curling and raising the tail while hiding the head and remaining motionless (Greene 1973, 1979; Jackson 1979). This behavior has been described in species as diverse as the South American False Coralsnake (Erythrolamprus aesculapii), Sao Paulo False Coralsnake (Simophis rhinostoma) (Sazima and Abe 1991), South American Hognose Snake (Xenodon dorbignyi) (Tozzetti et al. 2009), Neuwied's False Fer-de-lance (Xenodon neuwiedii), Wagler's Snake (Xenodon merremii), Günther's False Fer-de-lance (Xenodon guentheri) (Pedrozo et al. 2020), Western Coralsnake (Micruroides euryxanthus) (Greene 1988), Ringneck Snake (Diadophis punctatus), Yellow-bellied

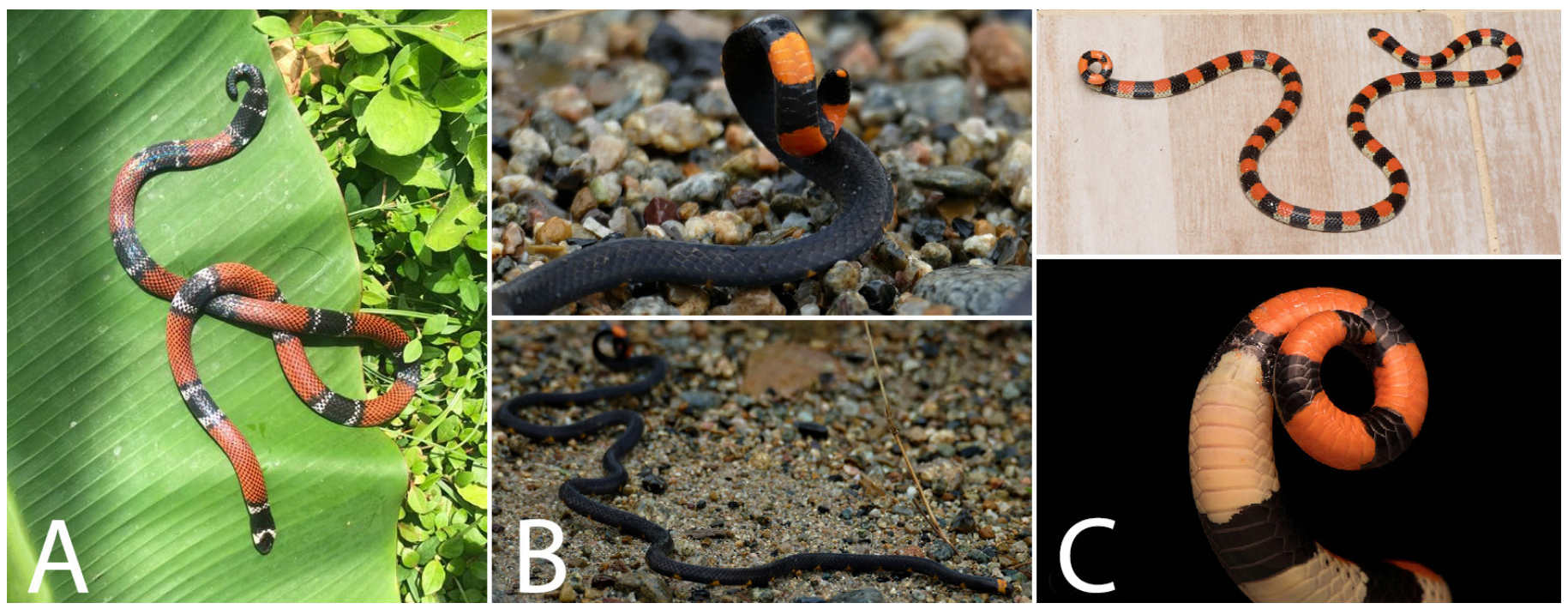

Fig. 1. Defensive head-mimicry in coralsnakes (Micrurus spp.): Andean Black-backed Coralsnake (Micrurus narducci) (A), Common Capuchin Coralsnake (Micrurus dumerilii dumerilii) (B), and Camila's Coralsnake (Micrurus camilae) (C). Photographs by Fredy Montero (A), Carlos Brand (B), and John Calderón (C). 
Seasnake (Hydrophis platurus), Black Groundsnake (Atractus elaps), Atlantic Central American Milksnake (Lampropeltis polyzona), African Gartersnake (Elapsoidea sundevallii), Blue Malaysian Coralsnake (Calliophis bivirgatus) (Greene 1973), and a number of coralsnakes in the genus Micrurus (Table 1). Greene (1973) suggested that head-mimicry might occur in all American coralsnakes, and the similar head and tail coloration in many species of Micrurus might render this behavior more effective (Jowers et al. 2019). Herein we present new records of head-mimicry in three species of Micrurus.

An Andean Black-backed Coralsnake (Micrurus nar- ducci), found on 29 July 2021 in the municipality of Villa Garzón, Putumayo, Colombia (elev. $400 \mathrm{~m}$ asl), coiled its tail as it was about to be photographed (Fig. 1A). A Common Capuchin Coralsnake (Micrurus dumerilii dumerilii), encountered on 24 October 2021 in the municipality of Turbana, Bolívar, Colombia (elev. $80 \mathrm{~m}$ asl), coiled its tail while it was being positioned for photography (Fig. 1B). A Camila's Coralsnake (Micrurus camilae), found on 26 November 2021 in the municipality of Apartadó, Antioquia, Colombia (elev. $20 \mathrm{~m}$ asl) coiled its tail when initially detected (Fig. 1C). All of the snakes were released after being photographed.

Table 1. Reports of defensive head-mimicry in snakes of the genus Micrurus.

Species

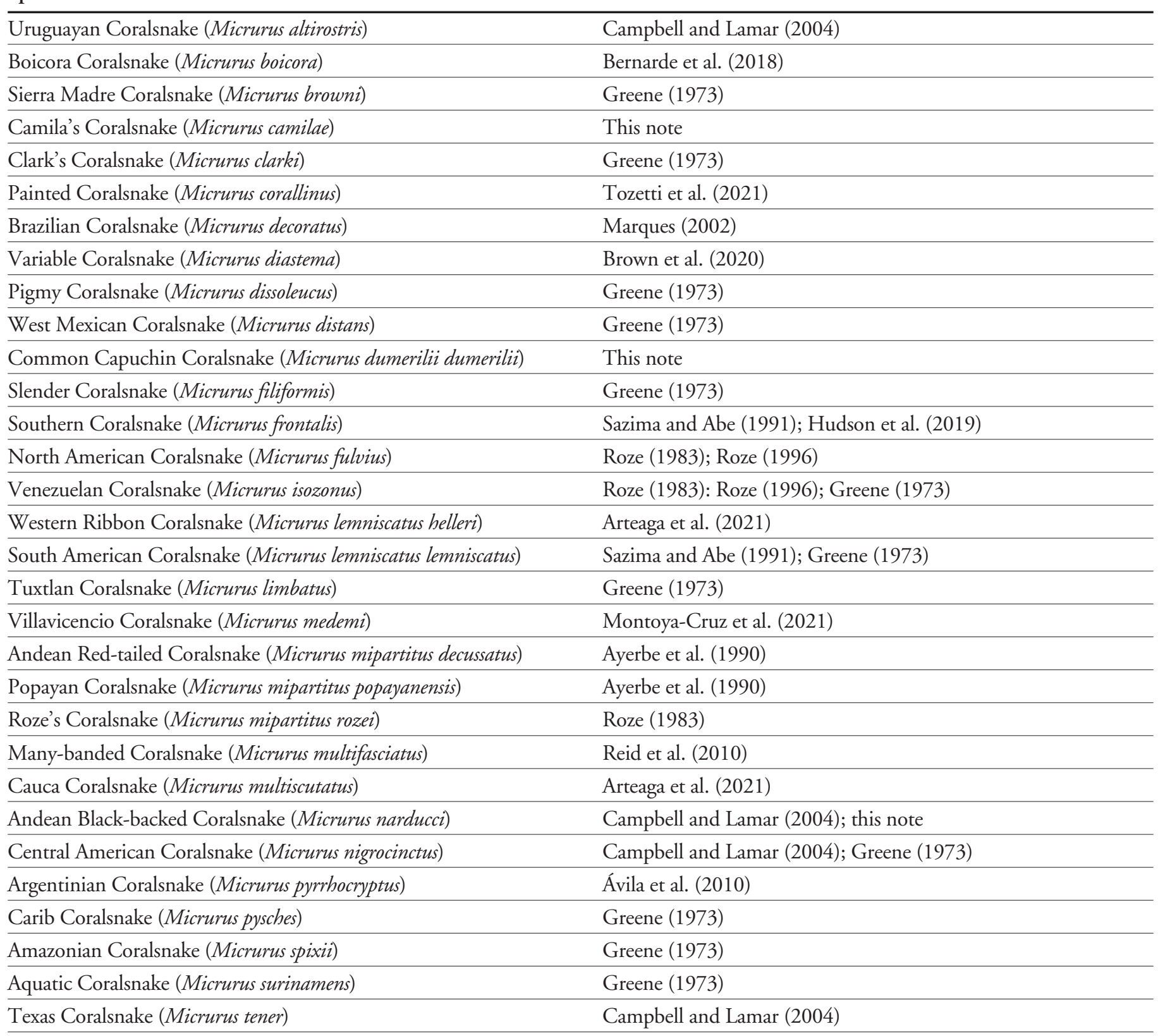

\section{References}

Campbell and Lamar (2004)

Greene (1973)

Greene (1973)

Tozetti et al. (2021)

Brown et al. (2020)

This note

Sazima and Abe (1991); Hudson et al. (2019)

Sazima and Abe (1991); Greene (1973)

Greene (1973)

Ayerbe et al. (1990)

Ayerbe et al. (1990)

Arteaga et al. (2021)

Campbell and Lamar (2004); Greene (1973)

Greene (1973)

Greene (1973) 


\section{Acknowledgements}

We thank the Urabá Nature Tours for interest in investigating snakes, and Fredy Montero and John Calderón for permission to use their photographs.

\section{Literature Cited}

Arteaga, A., L. Bustamante, and J.M. Guayasamin (eds.). 2021. Reptiles of Ecuador: Life in the Middle of the World. Universidad Tecnológica Indoamerica, Quito, Ecuador. https://doi.org/10.47051/MNHT9360.

Ávila, R.W., R.A. Kawashita-Ribeiro, V.L. Ferreira, and C. Strüssmann. 2010. Natural history of the coral snake Micrurus pyrrhocryptus Cope 1862 (Elapidae) from semideciduous forests of western Brazil. South American Journal of Herpetology 5: 97-101. https://doi.org/10.2994/057.005.0204.

Ayerbe, S., M.A. Tidwell, and M. Tidwell. 1990. Observaciones sobre la biología y comportamiento de la serpiente coral "rabo de Aji”" (Micrurus mipartitus). Descripción de una subespecie nueva. Novedades Colombianas 2: 30-41.

Bernarde, P.S., L.C. Batista, A. Diesel, and F.L. Franco. 2018. A remarkable new species of coralsnake of the Micrurus hemprichii species group from the Brazilian Amazon. Salamandra 50: 249-258.

Brodie, E.D., Jr, D.R. Formanowicz, Jr., and E.D. Brodie III. 1991. Predator avoidance and antipredator mechanisms: Distinct pathways to survival. Ethology, Ecology and Evolution 3: 73-77. https://doi.org/10.1080/0892701 4.1991.9525390.

Brown, T.W., M.B. Barazowski, and G. Lonsdale. 2020. Defensive tail-curling and head-mimicking behavior in a Variable Coralsnake, Micrurus diastema (Squamata: Elapidae) in Cusco National Park, Honduras. Reptiles \& Amphibians 27: 231-232. https://doi.org/10.17161/randa.v27i2.14187.

Campbell, J.A. and W.W. Lamar. 2004. The Venomous Reptiles of the Western Hemisphere. Cornell University Press, Ithaca, New York, USA.

Dalziell, A.H. and J.A. Welbergen. 2016. Mimicry for all modalities. Ecology Letters 19: 609-619. https://doi.org/10.1111/ele.12602.

DuVal, E.H., H.W. Greene, and K.L. Manno. 2006. Laughing falcon (Herpetotheres cachinnans) predation on coral snakes (Micrurus nigrocinctus). Biotropica 38: 566- 568. https://doi.org/10.1111/j.1744-7429.2006.00162.x.

Getelina, M.A., G. dos Santos, I. Busatto, R.C. Bortoluzzi, and M. Carvalho da Rocha. 2018. Climbing behaviour in Micrurus altirostris (Cope, 1860) (Serpentes, Elapidae) from an Atlantic rainforest in southern Brazil. Herpetology Notes 11: 437-439.

Greene, H.W. 1973. Defensive tail display by snakes and amphisbaenians. Journal of Herpetology 7: 143-161. https://doi.org/10.2307/1563000.

Greene, H.W. 1979. Behavioral convergence in the defensive displays of snakes. Experientia 35: 747-748.

Greene, H.W. 1988. Antipredator mechanisms in reptiles, pp. 153-234. In: C. Gans and R.B. Huey (eds.), Biology of the Reptilia. Vol. 16. Ecology B, Defense and Life History. Alan R. Liss, Inc., New York, New York, USA.

Hudson, A.A., M.A. Silva, R.M. Honório, and B.M. Sousa. 2019. Micrurus frontalis (Cerrado Coralsnake). Defensive behavior, reproduction, and melanism. Herpetological Review 50: 805-806.
Jackson, J.F. 1979. Effects of some ophidian tail displays on the predatory behavior of Grison (Galictis sp.). Copeia 1979: 169-172. https:// doi. org/10.2307/1443751.

Jowers, M.J., J.L. Garcia Mudarra, S.P. Charles, and J.C. Murphy. 2019. Phylogeography of West Indies coral snakes (Micrurus): Island colonisation and banding patterns. Zoologica Scripta 48: 263-276. https://doi. org/10.1111/zsc. 12346 .

Lopes de Assis, C., J.J. Magalhães Guedes, L.M. Gomes de Jesus, and R. Neves Feio. 2020. New defensive behaviour of the false coral snake Oxyrhopus rhombifer Duméril, Bibron \& Duméril, 1854 (Serpentes, Dipsadidae) in southeastern Brazil. Neotropical Biology and Conservation 15: 71-76. https://doi. org/10.3897/neotropical.15.e48564.

Marques, O.A. 2002. Natural history of the coral snake Micrurus decoratus (Elapidae) from the Atlantic Forest in southeast Brazil, with comments on possible mimicry. Amphibia-Reptilia 23: 228-232.

Montoya-Cruz, A., D. Mancera-García, and R.A. Díaz-Flórez. 2021. Defensive behavior in a Villavicencio Coralsnake, Micrurus medemi Roze 1967 (Squamata: Elapidae), in Colombia. Reptiles \& Amphibians 28: 483-484. https://doi.org/10.17161/randa.v28i3.15719.

Moore, T.Y., S.M. Danforth, J.G. Larson, and R.D. Rabosky. 2020. A quantitative analysis of Micrurus coral snakes reveals unexpected variation in stereotyped anti-predator displays within a mimicry system. Integrative Organismal Biology 2:1-15. https://doi.org/10.1093/iob/obaa006.

Pedrozo, M., M. Moroti, and E. Muscat. 2020. New defensive behaviour for Xenodon neuwiedii Günther, 1863 (Squamata, Dipsadidae) in a fragment of Atlantic Forest. Herpetology Notes 13: 863-865.

Reid, F.A, T. Leenders, J. Zook, and R. Dean. 2010. The Wildlife of Costa Rica: A Field Guide. Comstock Publishing Associates, Ithaca, NewYork, USA.

Rowe, C. and C. Halpin. 2013. Why are warning displays multimodal? Behavioral Ecology and Sociobiology 67: 1425-1439. https://doi.org/10.21203/ rs.3.rs-777244/v1.

Roze, J.A. 1983. New World coral snakes (Elapidae): a taxonomic and biological summary. Memorias do Instituto Butantan 46: 305-338.

Roze, J.A. 1996. Coral Snakes of the Americans: Biology, Identification and Venoms. Krieger Publishing Co., Malabar, Florida, USA.

Sazima, I. and A.S. Abe. 1991. Habits of five Brazilian snakes with coral-snake pattern, including a summary of defensive tactics. Studies on Neotropical Fauna and Environment 26: 159-164. https://doi.org/10.1080/01650529109360848.

Serafim, H. and M. Ribeiro Duarte. 2008. Tail mock-strike and hemipenis display in the Coral snakes, genus Micrurus (Elapidae): Epiphenomenon or deimatic behaviour? Herpetological Bulletin 104: 7-8.

Tozzetti, A.M., R.B. Oliveira, and G.M. Pontes. 2009. Defensive repertoire of Xenodon dorbignyi (Serpentes, Dipsadidae). Biota Neotropica 9: 175-163. https://doi.org/10.1590/S1676-06032009000300016.

Tozetti, A.M., S.A. Abrahão, R. Silveira, D. Loebmann, L.F. Toledo, R. Gray, and O.M. Entiauspe-Neto. 2021. Evolutionary dynamics shape two passive defensive mechanisms in Neotropical snake radiations. Phyllomedusa 20: 3-13. https://doi.org/10.11606/issn.2316-9079.v20i1p3-13.

Uetz, P., P. Freed, R. Aguilar, and J. Hošek (eds.). 2021. The Reptile Database. $<$ http://www.reptile-database.org $>$. 